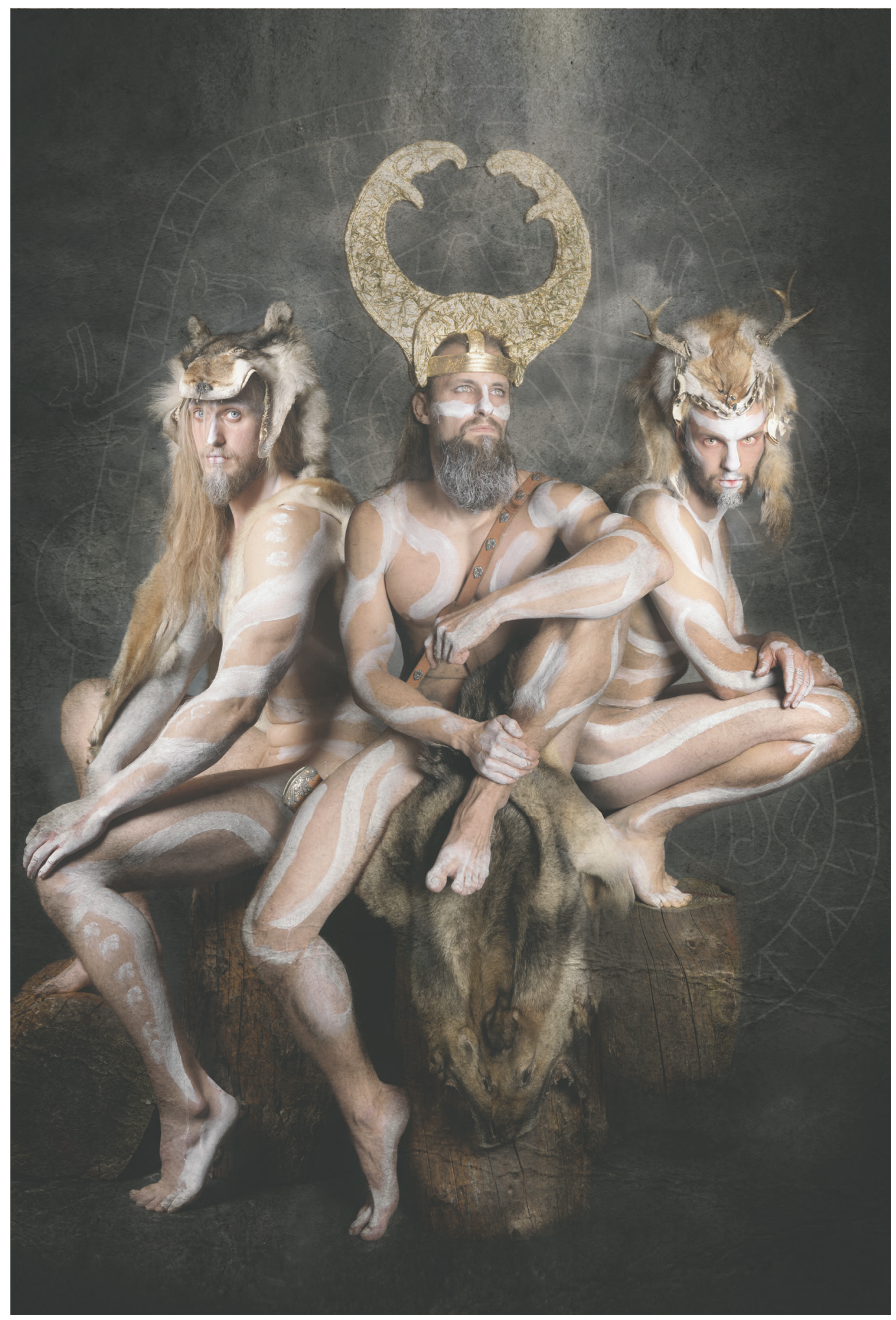

Jim Lyngvild, Berserkere, 2018. ㄱim Lyngvild 


\section{Vikingens udødelige \\ sang}

\section{En sammenligning af norrøne digte og helteportrætter $i$ Vikings (2013-) og Oehlenschlägers Regnar Lodbrok (1849)}

Vikinger er in disse år. Alene i Danmark vidner rekordbes $ø g$ på vikingemuseer og -centre om en stor interesse for vikingetiden (Bjerre 2016; Bohsen 2016; Poulsen 2017). Særligt har tv-kanalen History's succesfulde tv-serie Vikings (2013-) været med til at sætte Skandinavien på verdenskortet. Seriens fortælling om vikingen Regnar Lodbrog og hans sønners familiefejder og plyndringstogter får turister til at valfarte til lande som Danmark, Sverige og Island. Som et eksempel på fiktionaliseret historie har Vikings også haft indflydelse på museernes forskningsformidling. Spørgsmålet om grænsen mellem fiktion og fakta var omdrejningspunktet, da Nationalmuseet sidste år åbnede den kontroversielle udstilling "Mød vikingerne". Her deltog en af seriens skuespillere, Alex Høgh Andersen, i en åbningsdebat sammen med direktør Rane Willerslev, museumsinspektør Jeanette Varberg og designeren Jim Lyngvild, hvis fortolkning af vikingetiden udløste en heftig debat i medierne. ${ }^{\text {I Serien Vikings }}$ er imidlertid del af en længere tradition af fortællinger, som henter inspiration fra sagnhistorisk stof om vikingetiden. Traditionen nåede særlige højder i romantikkens Danmark, hvor flere antikvarer og digtere både diskuterede og genfortalte nordiske vikingesagn. Romantikkens genopdagelse og formidling af norrøn litteratur er den afgørende årsag til vikingernes status som nationale ikoner i Skandinavien. Sagnet om vikingen Regnar Lodbrog inspirerede også nationaldigteren Adam Oehlenschläger, der i 1849 genfortalte vikingens historie i heltedigtet Regnar Lodbrok.

I denne artikel vil jeg foretage en komparativ analyse af Vikings og Oehlenschlägers heltedigt med et særlig fokus på deres frie fortolkning af Regnars karakter og dødssang, som vi kender fra det norrøne digt "Krákumál". Jeg vil imidlertid ikke gå kronologisk til værks. I stedet vil jeg starte med den moderne tv-serie, hvorefter jeg præsenterer "Krákumál"s receptionshistorie og analyserer dens genkomst hos Oehlenschläger. Denne struktur har til hensigt at diskutere serien og heltedigtet i et større perspektiv og derved tydeliggøre, hvordan en serie som Vikings genopfinder en adaptationsform og interesse for norrøn litteratur, som kan spores tilbage til romantikken. 
Jeg vil på de følgende sider argumentere for, at inklusionen af dødssangen "Krákumál" har en afgørende betydning for fremstillingen af karakteren Regnar Lodbrog i både Vikings' afsnit "All his Angels" (2016) og Oehlenschlägers Regnar Lodbrok. Dødssangen er samtidig et billede på, hvordan serien og heltedigtet indskriver sig i genren fiktionaliseret historie, idet de genbruger kilder fra norrøn litteratur for at skabe en illusion om fortiden, i dette tilfælde vikingetiden. Jeg vil uddybe denne pointe i følgende afsnit, hvor jeg kort præsenterer Vikings' og Regnar Lodbroks brug af norrønt kildemateriale samt bevæggrundene for mit valg af serien og heltedigtet som analyseobjekter. Derefter vil jeg analysere Vikings' anvendelse af norrøn poesi, hvorefter jeg kortfattet berører "Krákumál”s receptionshistorie. På den baggrund vil jeg analysere Oehlenschlägers kendskab til dødssangen og dens optræden i heltedigtet, hvilket vil munde ud i en afsluttende diskussion om "Krákumál"s betydning for portrættet af vikingehelten i de to værker. Som hovedperson i Vikings (t.o.m. sæson fire) og heltedigtet bliver Regnar Lodbrog vikingetidens ansigt. Af samme årsag er de forskellige adaptationer af karakterens eventyr og dødssang med til at forme og udfordre vores opfattelse af vikingetiden som historisk periode.

\section{Inspiration og fortidsformidling}

De norrøne tekster fra middelalderens Island befinder sig i en gråzone mellem fakta og fiktion. Flere af dem er fyldt med overnaturlige skabninger som drager og trolde, mens andre refererer til historiske personer, der også findes i andre kilder. Usikkerheden omkring teksternes historiske autenticitet er ifølge Vikings' skaber Michael Hirst en begrundelse for at afvige fra det norrøne kildemateriale i serien ( $w w w$. history.org 18.12.2018, upagineret). Romantikeren Oehlenschläger afviger også fra middelalderens oldnordiske tekster, idet han udvider deres narrativ og derved rekonstruerer sagaen om Regnar Lodbrog.

Selv om Vikings' afsnit "All his Angels" og Oehlenschlägers heltedigt er vidt forskellige, hvad angår medie og historisk kontekst, vil jeg mene, at der er gode grunde til at sammenligne dem: Både serien og Oehlenschläger udviser en interesse i historien. Skaberne bag Vikings har konsulteret forskere og islandske forfattere, som udover at bidrage til seriens produktion også medvirker i History's sideløbende dokumentarer om vikingetidens kultur og skikke. ${ }^{2}$ Hvad angår Oehlenschläger, så var han en central del af kulturmiljøet i København, som dengang var hovedsædet for norrøne studier, og hvor forfattere og oldtidsforskere undersøgte og oversatte forskellige norrøne kilder. Den begrænsede adgang til norrøn litteratur i 1800-tallet betød, at størstedelen af befolkningen lærte vikingetiden at kende via diverse genfortællinger, der både udkom i bogform og udspillede sig på teaterscenen. Jeg betragter i denne sammenhæng både Vikings og Oehlenschlägers heltedigt som formidlingsprojekter, der genbruger tilgængelige oversættelser af og forskning om norrøn litteratur, som de derefter omsætter til fiktive og underholdende fortællinger på hver deres medieplatform. Skønt ingen af dem bestræber sig på at være fuldstændig historisk korrekte, er de begge vigtige aktører i den udbredte opfattelse af vikingetiden og -helten i henholdsvis det 21. århundrede og romantikken. 
Endelig benytter både Vikings og Regnar Lodbrok sig af nogle af de samme kilder, herunder Saxos Gesta Danorum (ca. 1200) og de islandske sagaer fra primært det 13. og 14. århundrede. Iblandt disse er Ragnar Lodbrogs saga, Ragnars saga loðbrókar og digtet "Krákumál”. Sagaen beretter om Regnars liv og senere hans død efter et mislykket togt i Northumbria, hvor han synger sin dødsang i Kong Ellas ormegård. Selv om Ragnars saga loðbrókar refererer til dødssangen, inkluderer den ikke selve sangen i sin helhed. Det gør derimod "Krákumál", som dateres til 1100-tallet. Digtet består af 29 strofer, hvor førstepersonsfortælleren Regnar beretter om sine heltegerninger og togter, hvorefter han reflekterer over sin død i Ellas ormegård. Til sidst udbryder han, at han ser frem til efterlivets gilde i Valhal, og at han vil møde døden med latter (Lassen 2016, 199). Både "Krákumál” og Ragnars saga loðbrókar indgår i en samling af norrøne prosatekster kaldet fornaldarsagaerne, som omhandler legendariske helte og sagnhistorier fra Skandinaviens vikingetid (Driscoll 2018, 8). Vikings og Regnar Lodbrok bringer hver især oversatte, nøje udvalgte passager fra "Krákumál", og i begge tilfælde er dødssangen tilpasset det portræt af Regnar, som seriens afsnit og heltedigtet lægger for dagen. For at forstå denne proces, vil jeg i de næste afsnit undersøge, hvordan serien og heltedigtet hver især anvender og adapterer sit norrøne kildeforlæg.

\section{"I shall not enter Odin's hall with fear"}

Canadisk-irske Vikings var oprindeligt tænkt som en miniserie, men har nu afsluttet hele fem sæsoner, der varierer mellem ti og tyve afsnit. Som manden bag serien fungerer Hirst både som manuskriptforfatter og medproducent. Han er velbevandret i genren historisk fiktion, da han har været manuskriptforfatter og producent på film som Elizabeth (1998), Elizabeth: The Golden Age (2007) og serien The Tudors (20072010). Med Vikings har Hirst forladt Tudordynastiet og kastet sit blik længere tilbage til vikingetiden og Europas tidlige middelalder. Hirst har efter eget udsagn mødt begejstring fra historikere og eksperter, som meddeler, at Skandinaviens interesse for vikingetiden er steget markant i kølvandet på seriens succes (Swinson 2016). I et interview på History's hjemmeside fastholder Hirst, at han har fravalgt de overnaturlige, fantasylignende elementer fra de norrøne kilder til fordel for det historiske indhold. Dog indrømmer han, at "it's always a drama, not a documentary. I'm a storyteller, and this is my saga" (www.history.org 18.12.2018, upagineret). Hirsts insisteren på en vis grad af historisk autenticitet, kombineret med hans forsvar for den frie fortolkning, har resulteret $i$, at kritikken omkring serien som regel er rettet mod dens blanding af historie og fiktion. Som Pernille Hermann har påpeget, er brugen af det historiske materiale og den potentielle virkelighedsforbindelse en del af seriens tiltrækningskraft. Hun tilføjer også, at serien samtidig må stå for skud for eksperters kritik, fordi den frit udvælger og sammensætter historiske informationer for at skabe det bedste drama (Hermann 2017).

En del af Vikings' tilstræbte autenticitet kommer til udtryk i dens inddragelse af norrøn litteratur, hvilket Gareth Lloyd Evans diskuterer i antologien Translating Early Medieval Poetry (2017). I sit kapitel advokerer Evans for, at Vikings bruger filmmediets virkemidler som kinematografi, lydspor og dialog til at producere oversæt- 
telser, der både er bogstavelige og kulturelle, idet de overfører originalkildernes ord såvel som deres stemning til seriens egen handling og univers (Evans 2017, 200). Evans' analyse dækker seriens første tre sæsoner, og han fokuserer på inddragelsen af primært tre eddadigte, "Völuspá”, "Grímnismál” og "Hávamál”. I Vikings er digtene enten oversat til engelsk - og er således tilpasset seriens primære sprog - eller også er de citeret direkte på det norrøne sprog. Som eksempel nævner Evans en episode, hvor Regnar citerer oversatte vers fra "Hávamál". ${ }^{3}$ Evans henviser også til seriens soundtrack, som frontfiguren i den norske neofolk-gruppe Wardruna, Einar Selvik, har været med til at udvikle sammen med komponisten Trevor Morris. Selvik optræder selv i tredje sæson, hvor han i baggrunden spiller på et middelalderinstrument, kraviklyren, mens han synger strofer fra "Völuspá" på originalsproget. Ifølge Evans inkluderer Hirst disse digte for at fortælle seerne om vikingernes mytologiske forestillingsverden. Samtidig passer digtenes tematiske indhold til de pågældende scener: Regnar citerer "Hávamál" for at identificere sig med digtets hovedperson Odin, som han sammenlignes med igennem hele serien. Selviks fortolkning af "Völuspá" er for de fleste seere "an appropriately ominous and 'medieval-sounding' piece of background music" (s. 203). Men de, der genkender digtet, vil imidlertid opdage, at "Völuspá"s allusioner til ragnarok afspejler de dramatiske begivenheder, der senere udspiller sig under sangen, og som foregriber det kaos, seriens vikinger har i vente. Med andre ord formår de norrøne digte at udvide seriens sagnhistoriske univers og de enkelte handlingsforløb.

Spørgsmålet er, hvorfor Vikings vælger at citere norrøne digte, enten på engelsk eller originalsproget, når der sandsynligvis kun er få seere, som vil opfatte referencerne. Til det svarer Evans, at alle digtene tydeligvis er nøje udvalgt, og eftersom de passer til den pågældende scene, behøver de ikke engang at blive oversat. Vikings benytter sig derved af en form for "contextual translation" (s. 203), hvor originaldigtets kontekst, forstået som dens mytologiske forhistorie og centrale stemning, bliver overført til seriens filmmedie. Dette tyder på, at seriens skabere har konsulteret eksperter, der er fortrolige med de norrøne digtes indhold og fortællinger, og digtene er bevidst blevet inkorporeret i Vikings, enten som dialog eller baggrundsmusik. Kilderne oversættes og modificeres til seriens handlingsforløb, der ligeledes tilpasser sig det enkelte digts indhold og stemning.

Evans' teori om denne kontekstuelle oversættelsesform kan anvendes for at forstå Vikings' reference til Regnars dødssang. I den fjerde sæson, episode femten, "All his Angels", møder seriens Regnar Lodbrog sit endeligt i kong Ellas hænder. Han bliver hånet, tæsket og indespærret i et bur som et vildt dyr. I den sidste del af episoden får vi afsløret, at buret hænger oven over et dybt hul i skovbunden, hvor Ellas slanger venter. Før Ellas soldater trækker i burets faldlem, citerer Regnar nogle af de sidste vers fra "Krákumál" på engelsk. Her afviger serien fra de tre kilder, som omtaler dødssangen. Både Ragnars saga loðbrókar og Saxos krønike nævner Regnars dødssang, men de inkluderer ikke selve digtet "Krákumál". I alle tre kilder får vi imidlertid fortalt, at Regnar synger sine sidste ord, mens han bliver bidt af slangerne. Sådan forholder det sig ikke i Vikings' episode. Her siger han dem i stedet højt med en trodsig stemme rettet mod Ella og hans folk, som tavst ser på. Som med inklusionen af "Völuspá" i tredje sæson vælger skaberne desuden at genfortolke noget 
af det norrøne materiale som underlægningsmusik. Selv om Regnar ikke synger sin dødssang, får seerne alligevel en sang i form af Selviks nummer "Snake Pit Poetry", som afspilles i det øjeblik, vi får afsløret Ellas slangehul i skoven. Sangen indeholder norrøne citater fra Regnars dødssang - her menes ikke "Krákumál”, men dødssangen, som den optræder i Ragnars saga loðbrókar. Derudover forvarsler den Regnars død og intensiverer episodens underliggende, melankolske stemning.

Ligesom med eksemplerne i Evans' artikel forekommer der en kontekstuel oversættelse af "Krákumál” i episoden "All his Angels". Selv om Regnars sangstemme er overdraget til Selvik, udtaler Regnar selv ordene fra "Krákumál”, som har undergået en lettere omskrivning. Serien har nøje udvalgt de sidste strofer, hvor Regnar reflekterer over sin død, som han møder med oprejst pande: "I shall not enter Odin's hall with fear" (Donnely 2016), lyder det i afsnittet. Serien har overført Regnars dødsforagt fra "Krákumál" til hovedpersonen i Vikings, der leverer sine tanker med samme trodsighed. Skønt episoden ikke ændrer "Krákumál"s indhold direkte, men snarere tilpasser dødssangen til resten af afsnittet, har "Krákumál" en helt anden betydning for seriens hovedperson. Dette vender jeg tilbage til i artiklens sidste afsnit.

Vikings' særlige oversættelse af eddadigtene har efter Evans' mening en forskningsmæssig relevans. Fordi serien er fiktiv og derfor må eksperimentere med historiske kilder og norrøn litteratur, forestiller den sig, hvordan norrøne digte kunne være blevet fremført i vikingetiden. Derved giver Vikings os et bud på fortidsritualer eller skikke, som forskningen aldrig vil kunne dokumentere (Evans 2017, 209). Evans slutter desuden, at seriens måske største bidrag til forskningen er, at den sørger for at udbrede og formidle norrønt stof til et bredt publikum og derved potentielt tiltrækker flere studerende, som vil lære mere om norrøn kultur og sprog. Dette skyldes Vikings' særlige kontekstuelle oversættelse, som "pushes the translation of Old Norse poetry into new territory, while simultaneously making it accessible to a far wider audience than is usually the case" (s. 212). Vikings har derved en dobbeltsidet formidlingsevne, eftersom den henvender sig til både norrøne forskere og seere med en interesse for vikingetiden og historisk drama.

\section{"Krákumál” før Vikings}

Hirst er langt fra den første, som anvender "Krákumál" til at portrættere vikingernes forståelsesverden og Regnars krigermentalitet. Regnar Lodbrogs dødssang har en lang og indflydelsesrig receptionshistorie, som går helt tilbage til 1600-tallet. Det var et af de første norrøne digte, som blev oversat til det engelske sprog, og det blev anset som en vigtig kilde til Englands historie (Rix 2009, 53). ${ }^{4}$ Digtet kom i en dansk oversættelse allerede i 1652 som en del af Christen Berntsen Viborgs bog Bildur Danskum, det er, den danske bilde elleer Kaarde presenterende en gamle Kiempe Vise om danske Mands tapperhed oc mandelige gierninger, dictet aff Regner Lodbrog. Viborgs version var en dansk genudgivelse af Ole Worms latinske oversættelse fra 1636 (Lassen 2016, 199). Worm var den første til at oversætte "Krákumál” i samarbejde med islændingen Magnús Ólafsson, som i 1632 sendte ham en transskription af det oldnordiske digt, inklusiv en dansk oversættelse og kommentarer (Rix 2009, 54). Worms udgave af "Krákumál" optræder i appendikset til bogen Literatura Ru- 
nica (1636), som hurtigt fik en afgørende indflydelse på den europæiske reception af norrøn litteratur. Worms version havde imidlertid flere oversættelsesfejl, navnlig en misforståelse af en norrøn kenning i dødssangens 25. strofe. På originalsproget lyder det, at Regnar ser frem til at drikke mjød fra bjúgviðir hausa ("hovedernes bugtegrene" eller "horn"). Worm oversatte imidlertid kenningen til ex concavis crateribus craniorum ("kraniernes tomme hulrum"). Dermed opstod der en forestilling om, at vikingerne drak mjød fra deres fjenders kranier, og oversættelsesfejlen fik flere til at stemple vikingerne som uciviliserede barbarer (Lassen 2016, 195; Rix 2009, 55). Oversættelsesfejlen fik store konsekvenser i det 18. og 19. århundrede, hvor "Krákumál" fik en paradigmestatus som et af de digte, der havde størst indflydelse på opfattelsen af norrøn poesi. Udover danske og engelske oversættelser udkom digtet også på hollandsk, fransk, tysk og svensk allerede før år 1800. På grund af sin popularitet i Europas antikvar- og forfatterkredse kom Regnars dødssang hurtigt til at repræsentere vikingetiden som en barsk krigerkultur med passionerede helte, der drak fra kranier og kun havde latter tilovers for døden (Clunies Ross 2001, 91; Lassen 2016, 199).

Worms oversættelsesfejl blev først rettet i 1814 og 1821 af islandske Finn Magnusson og den danske oldtidsforsker Carl Christian Rafn (Lassen 2016, 199). Rafn er en af 1800-tallets største bidragsydere til den norrøne forskning. Han var den første til at bruge betegnelsen fornaldarsagaerne til at kategorisere de legendariske sagaer fra Island, som han redigerede og udgav både på dansk (Nordiske KæmpeHistorier I-III, 1821-18265) og på originalsproget (Fornaldar Sögur Nordrlanda IIII, 1829-1830) (Lassen 2018, 324ff.). I sin artikel om fornaldarsagernes oversættelseshistorie i Danmark gør Annette Lassen dog opmærksom på, at den samlede mængde af gendigtninger af fornaldarsagaerne langt overstiger oversættelserne, især hvad angår sagaen om Regnar Lodbrog (s. 342, 346). I den forbindelse nævner hun Oehlenschläger, som havde behandlet heltefiguren allerede i 1840, ni år før Regnar Lodbroks udgivelse.

\section{Oehlenschlägers Nordiske Oldsagn}

Oehlenschläger udgav i 1840 Nordiske Oldsagn på opfordring af Selskabet for Trykkefrihedens rette Brug, der stod for publiceringen. Nordiske Oldsagn indeholder historier fra både Saxo og fornaldarsagaerne, og Oehlenschläger har benyttet sig af Anders Sørensen Vedels Saxo-oversættelse fra 1575 samt Rafns danske udgave af fornaldarsagaerne. Bogen indeholder fortællinger om velkendte sagnfigurer, som både Oehlenschläger og hans samtidige behandlede, f.eks. Amleth, Sigrid, Hrolf Krake og heltene fra Vølsungernes saga og Ragnar Lodbrogs saga. Nordiske Oldsagn er en sammenblanding af fortællinger, som Oehlenschläger har behandlet i sit forfatterskab, ${ }^{6}$ og fortællinger, som han senere ville genfortolke, herunder Regnar Lodbrok. Kaster man et blik på den sidste halvdel af hans forfatterskab, tyder meget på, at Rafns danske oversættelse af fornaldarsagaerne vedligeholdte eller delvist genoplivede Oehlenschlägers forkærlighed for det norrøne stof. Efter Rafns Nordiske Kæmpe-Historier og Nordiske Fortids Sagaer, skriver Oehlenschläger således Væringerne i Miklagaard (1827), Hrolf Krake (1828), Ørvarrods Saga (1841) og 
Regnar Lodbrok, der alle bygger på fortællinger fra fornaldarsagaerne i mere eller mindre grad. Rafns danske oversættelse har sandsynligvis udvidet Oehlenschlägers kendskab til norrøn litteratur, og det har været en nyttig kilde, eftersom han var knap så fortrolig med det norrøne sprog og derfor anvendte paralleloversættelser (Præstgaard Andersen 1981, 13).

I sin introduktion til Nordiske Oldsagn udtrykker Oehlenschläger sin tilfredshed over, at man nu er begyndt at indsamle og bevare flere oldtidsfund (Oehlenschläger 1840, 2). Som Robert Rix også har påpeget, var Oehlenschläger fortaler for restaureringen og bevaringen af historiske oldtidsmonumenter, og hans ambitioner vidner om den tætte udveksling mellem poeter og antikvarer i 1800-tallets København. Hans introduktion i Nordiske Oldsagn henviser måske til året 1812, hvor de danske museer åbnede for offentligheden. Før 1812 havde museerne kun været tilgængelige for antikvarer, historikere og digtere, som færdedes i de samme kredse (Rix 2015, 438ff.). Oehlenschläger har ligeledes skrevet Nordiske Oldsagn med et tiltænkt mål for øje. Han argumenter for, at oldtidssagaerne, ligesom oldtidsfundene, bør være tilgængelige for den almene læser: "Hvad gavne selv Oversættelserne Mængden, naar [...] den afskrækker, ikke blot Almuesmanden, men endog de fleste Andre, hvis Fag eller Ynglingssyssel Historien ikke er, fra at læse dem?" (Oehlenschläger 1840, 2-3).

Hans intention om at formidle norrøn litteratur til den almene befolkning kan sammenlignes med Hirsts formidling af norrøn poesi til et bredt publikum bestående af både tv-serieentusiaster og folk med en særlig interesse for historisk drama og vikingetiden. Oehlenschlägers norrøne dramaer blev hyppigt opført ${ }^{7}$ og flere oversat til især tysk, blandt andet af forfatteren selv. Han udbredte derved de norrøne sagnfortællinger til et både dansk og tysk publikum. I det 21. århundrede har Vikings fornyet og udvidet offentlighedens interesse for vikingetiden, på trods af den åbenlyse sammenblanding af fakta og fiktion. Grænsen mellem fakta og fiktion, mellem historie og nutidig kunstnerisk frihed, optager også Oehlenschläger. ${ }^{8}$ Han indrømmer i introduktionen til Nordiske Oldsagn, at denne bog imidlertid afviger fra hans tidligere adaptationer, idet han ikke har tilføjet noget nyt til teksterne. Han har ikke behandlet dem som digter, der ligesom guldsmeden former malmen i bjerget og "danner smukke Kar deraf, til Nytte og Fornøielse" (s. 3). Han skriver, at han blot har "bragt nogle Klumper i Stampeværket, for at skille dem ved Steen og Gruus, saa at mine Landsmænd med Lethed kunne lære at kiende disse Ærtser i deres naturlige Tilstand, og giemme udsøgte Stykker deraf paa egne Hylder" (s. 3). Oehlenschläger fungerer mere som en redaktør end egenlig forfatter i Nordiske Oldsagn. Alligevel har han tilføjet noget nyt i kapitlet "Regnar Lodbroks Saga", som strækker sig over 19 sider. I modsætning til Saxo og Ragnars saga loðbrókar, hvor "Krákumál" ikke indgår, vælger Oehlenschläger at inkludere den sidste strofe fra dødssangen, som ender med de berømte ord “af Døden leer jeg!” (s. 134). Endvidere diskuterer han den berygtede oversættelsesfejl, da han skal introducere sagaen:

Regnar Lodbroks Dødssang (hvoraf her kun meddeles sidste Vers) har længe givet Anledning i Udlandet til en Misforstaaelse, der er bygget paa en feil Oversættelse. Man vilde af Regnars Dødsang bevise den nordiske Gudelæres Barbari, fordi, efter den, Heltene i 
Valhal drak Miød af Fiendernes Hjerneskaller. Men Ordene: Ur biugvidum hausa betyde: 'af Hovedernes krumme Træer, eller Bærter.' Det vil sige: Drikkehorn. (s. 120-121)

Oehlenschläger er opmærksom på, at vikingernes barbariske image i høj grad er et produkt af receptionshistorien. Som modsvar ønsker han, at læseren skal anerkende den litterære værdi i den norrøne litteratur, der, på trods af at være voldsom og barsk, også besidder lidenskab og en indre sandhed om oldtidens forestillingsverden (s. 5ff.). Udover at tilføje den sidste strofe fra "Krákumál" kondenserer og omrokerer han visse passager i "Regnar Lodbroks Saga". Eksempelvis begynder han med fortællingen om Thora Borgarhjort, som Regnar vinder til kone - til forskel herfra åbner Ragnars saga loðbrókar med fortællingen om Regnars anden kone Kraka (Aslaug). Oehlenschlägers ændringer i Nordiske Oldsagn er imidlertid minimale sammenlignet med hans frie fortolkning i Regnar Lodbrok, hvor han frembringer en helt anden type helt.

\section{Oehlenschlägers Regnar Lodbrok}

I Regnar Lodbrok bringer Oehlenschläger ikke bare "Klumper i Stampeværket". Tværtimod genfortæller han sagaen med frie hænder på langt mere plads. Han har valgt at skrive Regnar Lodbrok som et heltedigt med enderim, der varierer i struktur og antal vers og ligner folkeviseformen til forveksling. Flere danske litteraturhistorier har overset bogen, og digtet er heller ikke blevet genoptrykt som individuelt værk siden 1849. Det fremgår imidlertid af Oehlenschlägers breve, at Regnar Lodbrok har behaget samtidens publikum på lige fod med skuespillet Kiartan og Gudrun (1847), der blev opført i samme periode (Oehlenschläger 1990, 379). Han reflekterer også over det faktum, at Regnars historie er velkendt blandt flere danskere, og at deres respons på hans fortælling kan oversættes til karakteren "Ug +" (s. 366). Han lægger heller ikke skjul på, at han med Regnar Lodbrok har fundet glæde i at kaste sig over en "kraftig barbarisk Tid" (s. 365), der har udgjort et modstykke til Treårskrigens (1848-1850) smålighed og galskab (s. 365). Heltedigtet udkom desuden et år efter Christian VIII's død; en begivenhed, som også optager Oehlenschläger (1851, 283), og som måske har motiveret ham til at behandle Regnars dødssang, der ligeledes markerer en dansk kongedød.

Selv sammenligner Oehlenschläger heltedigtets form og tone med sin trilogi Helge (1814) (Oehlenschläger 1990, 365) - et værk, der i modsætning til Regnar Lodbrok har nydt stor anseelse i Oehlenschlägerforskningen. Manglen på receptionshistorie og forskning i Regnar Lodbrok afspejler en større forskningstendens, der tilgodeser Oehlenschlägers ungdomsværker frem for hans senere forfatterskab. At forfatteren selv drager en parallel mellem heltedigtet og Helge, problematiserer denne forskningstendens, særligt fordi Regnar Lodbrok også fik en nogenlunde modtagelse ifølge Oehlenschlägers breve. ${ }^{9}$ Derfor finder jeg, at en analyse af Regnar Lodbrok godt kan give et værdifuldt indblik i hans samlede formidling og gendigtning af norrøn litteratur, også selv om heltedigtet er blevet overset i forfatterens receptionshistorie.

I Regnar Lodbrok har Oehlenschläger sandsynligvis benyttet sig af Saxo og Ragnars saga loðbrókar (sikkert Rafns version i fornaldarsagaerne), men han afviger 
fra begge tekster på flere måder. Blandt andet inkluderer han skjoldmøen Lathgertha i digtets første sang; en karakter som optræder hos Saxo, men ikke i sagaen. Hos Saxo forlader Regnar Lathgertha, da han gifter sig med Thora, men hos Oehlenschläger fravælger Regnar hende med det samme, fordi han ikke kan forlige sig med hendes maskuline træk. Han fortæller hende, at "Manden sig med Manden / Umuligt gifte kan" (Oehlenschläger 1849, 17). Lise Præstgaard Andersen har refereret til denne episode i Regnar Lodbrok, og hun fokuserer på de norrøne kvindeskikkelser for at illustrere, hvordan Oehlenschläger rekonstruerer sagnstof ud fra sin egen digteriske sans. I den forbindelse henviser hun til fornaldarsagaerne, der kan sammenlignes med triviallitteratur, hvor karaktererne er idealiserede og mangler psykologisk dybde. Originalteksternes mangler har kun været en fordel for Oehlenschläger, der har haft frie tøjler til at udbrede karakterernes personlighed (Præstgaard Andersen 1981, 14ff).

Hvor Præstgaard Andersen fokuserer på de norrøne kvinder, vil jeg beskæftige mig med helten Regnar, som hos Oehlenschläger får tildelt mere nuancerede og følsomme træk end i middelalderteksterne. Faktisk ser vi disse træk komme til udtryk, når de norrøne kvinder, Thora og Aslaug, konfronterer ham. I Ragnars saga loðbrókar finder vi en Regnar, der ifølge Elizabeth Ashman Rowe ikke er en ideel kongefigur. Hvad angår hans mislykkede togt og død i Northumbria, tilføjer hun, at "his demise is explicitly described as the result of his own stupidity" (Rowe 2009, 352). Oehlenschlägers Regnar er til sammenligning mere kæk, idealiseret og følsom. Netop hans følsomme side bliver fremhævet i Regnar Lodbrok, hvor hans personlighed fungerer som et mere positivt modstykke til sagaens Regnar. Eksempelvis tilføjer Oehlenschläger en rørende scene, da Regnar nærer følelser for Aslaug og derfor har skyldfølelse over for sin afdøde kone Thora:

64 Den Silkesærk, som Thora Hiort ham gav,

Og som han atter vilde Kraka skienke.

Mon ei hun vendte sig dybt i sin Grav,

Ved paa min Letsind, Troløshed at tænke?

Fra Freias Sol hun saae mig, svag og lav,

At ville bryde Kærlighedens Lænke.

Saa tænker han, men tvinger Hiertets Kummer;

I aarle Morgenstund han faldt i Slummer. (Oehlenschläger 1849, 79)

Regnar drømmer derefter om Thora, som siger, at hun aldrig vil stå i vejen for hans lykke, og hun beder ham indirekte om at gifte sig med Aslaug for børnenes og Danmarks skyld. Da Regnar vil omfavne hende, ender han dog med at favne "den lette Luft" (s. 80), og Thoras døde ånd forsvinder. Oehlenschläger opfinder her en scene, der udgør en følsom parentes i fortællingen, og som uddyber Regnars karakter. Som læsere forstår vi bedre, hvorfor han er i stand til at gifte sig med Aslaug efter at have sørget så længe over Thoras død. Også senere afviger Oehlenschläger fra sagaen og Saxo i forbindelse med Regnars ægteskab. I de to tekster fra middelalderen har Regnar giftet sig og fået børn med Aslaug, da han drager til Sverige og får tilbudt et ægteskab med kongens datter. Han godkender trolovelsen, men holder det hem- 
meligt for Aslaug, som dog har hørt nyheden fra tre fugle. Hun fortæller da Regnar, at hun er af adelig slægt som datter af Sigurd Fafnersbane og valkyrien Brynhilde. Derefter forudser hun, at deres næste søn vil blive født med en slange i øjet, som bevis på hendes ord. Først da Regnar ser dette bevis med sønnen Sigurd, fravælger han det planlagte giftermål (Lassen 2016, 156ff). Episoden er anderledes hos Oehlenschläger. Allerede i Sverige er Regnar tro mod Aslaug, idet han forsvarer hende over for kong Sixten, som klandrer Regnar for at have giftet sig med en kvinde under hans stand (Oehlenschläger 1849, 87). Regnar nægter åbent giftermålet med Sixtens datter Ingeborg, før han vender hjem til Danmark. Hans tavshed over for Aslaug skyldes således ikke trolovelsen (som i sagaen og Saxo), men hans afvisning af Ingeborg, hvilket har sat hans venskab med Sixten på spil. Aslaug roser ham imidlertid for hans loyalitet, og vi får endnu en gang et mere positivt billede af Regnar.

Oehlenschläger ændrer også Regnars karakter drastisk i forbindelse med hans tilfangetagelse i England og hans dødssang i Ellas ormegård. Hos Saxo og i sagaen lyder det, at Regnar ikke røber sin identitet over for Ella. Først da Regnar synger sin sang i ormegården, nærer Ella mistanke om, at fangen er Ragnar Lodbrog, som han ellers ikke ville dræbe af frygt for sønnernes hævn. Hos Oehlenschläger afslører Regnar heller ikke sin identitet, men udgiver sig for at være en anden:

6 Hvo est du? spurgte Kongen ham nu;

Hvad søger paa Bretlands Kyster du?

Ham svared Regnar: Jeg drog med en Drot,

En Viking, der tyktes om Striden godt.

Og jeg beklager hans Heltekald!

For resten er jeg Kong Regnars Skiald. (s. 138)

For at forstå Regnars udsagn i ovenstående strofe, må man først tage Oehlenschlägers samlede portræt af helten i betragtning. Ligesom i sagaen og Saxo bryder Regnar ud i sang, og det samme gør flere andre karakterer. Men Oehlenschläger fremhæver åbenlyst Regnars skjaldeidentitet, da Regnar f.eks. siger til Thora: "Skjaldekunsten høit jeg agter; / Selv en ægte Skiald at vorde, / Jeg ved Harpen eftertragter" (s. 60). Oehlenschlägers Regnar beundrer skjaldene, han vil selv være en, og Thora sammenligner ham endda med skjaldeguden Bragi. Regnars længsel efter skjaldekunsten er af og til i konflikt med hans rolle som kriger. Efter Thoras død dedikerer han sig fuldstændig til Thor, hvorefter krig og plyndringstogterne fungerer som en flugt fra hans sorg (s. 65), som han ellers har svært ved at give udtryk for: "Ikke Regnar kunde græde, / Men hans Hierte kunde bløde" (s. 62). Når fortvivlelsen rammer Regnar, forholder han sig tavs og isoleret. Ved at ændre hans personlighed lemper Oehlenschläger bevidst det mere bryske portræt af Ragnar, som vi finder hos Saxo og i den islandske saga.

Når Regnar hos Ella udgiver sig for at være skjald, kan det tolkes som et fors $\varnothing g$ på at forlige hans krigerrolle med den skjalderolle, som han efterstræber. Flere Oehlenschlägerforskere, herunder Præstgaard Andersen og Marie-Louise Svane, har karakteriseret Oehlenschlägers søgen efter balance og harmonisering som en central del i forfatterskabet (Præstgaard Andersen 1981, 8; Svane 2008, 123). Denne 
harmonisering kan genfindes i karakteren Regnar Lodbrok, der ved at udgive sig for at være sin egen skjald endelig forener sine skjaldedrømme med krigerfiguren og derved finder en udtryksform for sine følelser. Tanken om skjaldenes sange som middel til udødeliggørelse er en afgørende motivation bag Regnars heltegerninger, og i Ellas ormegård lykkes det ham at udødeliggøre sig selv som skjald. Han mindes sine sejre, og han insisterer endda på at medbringe sin harpe til ormegården, hvor vi får at vide, at han slår strengene an "Med øvet Haand" (Oehlenschläger 1849, 143). Ligesom i Nordiske Oldsagn inddrager Oehlenschläger "Krákumál" i forbindelse med Regnars død. Dødssangen skiller sig ud fra resten af digtet, idet den har en anden rimstruktur og verslængde, så læseren får indtrykket, at det norrøne digt faktisk optræder i Oehlenschlägers tekst. Det er imidlertid ikke tilfældet. Oehlenschläger inkluderer kun ti strofer ud af de 29, og han oversætter deres første vers Hjoggum vér með hjörvi ("Sværdene blev svundet") på forskellig vis - som bl.a. "Stærke svunge vi Sværdet", "Sagte da hvinede Sværdet" og "Sværd paa Skioldene klinge" (s. 143, 144, 145). Han ændrer også de sidste strofer fra førstepersons- til en tredjepersonsfortæller, hvor det blandt andet lyder, at: "Regnar reiser med Ære!" (s. 147) og "Leende gaaer han i Døden!" (s. 148). Valget af tredjepersonsfortæller skyldes muligvis, at bogens Regnar derved kan skjule sin sande identitet over for Ella. Endelig indsætter Oehlenschläger flere følsomme passager, hvor Regnar besynger Thoras og Aslaugs skønhed og senere begræder tabet af Thora og deres to sønner, Erik og Agnar (s. 146).

Oehlenschlägers udgave af "Krákumál" genfortæller Regnars eventyr i Regnar Lodbrok, og han lægger en særlig vægt på Regnars sorg og selvrefleksion. I den sidste strofe affinder Regnar sig endda med sin egen død, og han finder en vis ro heri, da han synger "Men det maa nu saa være" (s. 147). Dødssangen "Krákumál" i Regnar Lodbrok er derved ikke en oversættelse, men en nuanceret rekonstruktion i andet led, om man vil: Det er en rekonstruktion eller genfortælling af Oehlenschlägers egen rekonstruktion af kilderne om Regnar Lodbrog. Hos Oehlenschläger får vi en krigerskjald, der fortæller sin livshistorie, sådan som forfatteren har fortolket den. Regnar er her en sympatisk helt, der må omfavne sin følsomme side og skjaldeevner for at kunne dø i fred. Med dødssangen går Regnars dobbeltrolle som kriger og skjald op i en højere enhed, og sangen afspejler, hvordan Oehlenschläger konstant behandler og forhandler de to sider i karakteren Regnar. Samtidig kan den rekonstruerede dødssang læses som en manifestation af forfatterens egen behandling af middelalderkilden. Dette medfører, at heltedigtet får tilført et nuanceret, intertekstuelt lag, hvorved værket adskiller sig endnu mere fra de norrøne kilder, som det bygger på.

\section{Vikings og Regnar Lodbrok}

Både Oehlenschlägers heltedigt og serien Vikings bruger "Krákumál" til at genfortolke vikingen Regnar Lodbrog. Ligesom hos Worm og antikvarerne i det 18. og 19. århundrede bruger seriens skabere og Oehlenschläger dødssangen til at repræsentere forestillingen om vikingens mentalitet. Begge fiktive fortællinger har det tilfælles, at de undgår Worms oversættelsesfejl og derfor udfordrer det barbariske billede 
af vikingen. Oehlenschläger gør opmærksom på misforståelsen i Nordiske Oldsagn, og i episoden "All his Angels" udbryder Regnar: "Soon I shall drink ale from curved horns" (Donnely 2016, min kursivering). Ligesom i heltedigtet præsenterer Vikings os for en Regnar, der er mere kompliceret end den helt, vi møder i den norrøne saga og hos Saxo. Men hvor Oehlenschläger diskuterer Regnars splittelse mellem krigerog skjalderollen, er Vikings' Regnar snarere splittet mellem forskellige religioner. Hans kamp er en ideologisk kamp, mellem hedenskab og kristendom, hvilket er et centralt emne i hele serien. I "All his Angels" vælger Regnar imidlertid at vende ryggen til begge trosretninger. Da han indespærret i sit bur bliver fragtet gennem skoven af Ellas hær, forestiller han sig en samtale med seeren fra sin hjemby Kattegat. Han erklærer direkte, at han ikke tror på gudernes eksistens, og han ender dermed med at fremstå som en form for ateist, der fornægter alle religioner for at kunne kontrollere sin egen skæbne. Hirst har muligvis valgt at portrættere Regnar således for at gøre det lettere for moderne seere at identificere sig med ham.

Regnars ateistiske overbevisning har imidlertid også konsekvenser for hans citater fra "Krákumál". I stedet for at være en personlig refleksion over Regnars bedrifter og en higen efter det kommende efterliv i Valhal er Regnars dødsang i Vikings snarere en slags optræden, som har til formål at vække frygt hos Ella og hans mænd, som nu kan se frem til sønnernes hævn. Han fremsiger ikke ordene, fordi han tror på efterlivet, snarere tværtimod. I Vikings får vi vers fra "Krákumál"s 25. og 29. strofe, som har været sætstykker i dødssangens receptionshistorie. ${ }^{\text {Io }}$ Med Evans' teori in mente kan man argumentere for, at serien her foretager en kontekstuel oversættelse, hvor det norrøne digts motiv om den trodsige og dødsforagtende helt overføres til filmmediet. Hvad der imidlertid er ændret, er selve leveringen af digtet. Ikke alene taler Vikings' Regnar frem for at synge, han tror heller ikke på ordenes løfte om, at han snart skal drikke mjød i Odins hal. Dette gør scenen endnu mere tragisk, særligt fordi Ella godt ved, hvem Regnar er og ikke skyr nogen midler for at give ham den mest pinefulde død.

Vikings oversætter nøje udvalgte passager fra "Krákumál", men heltens indstilling til digtets indhold er altså ændret markant. Til forskel herfra vælger Oehlenschläger at inkludere dødssangen som en reference. Selv om "Krákumál" fandtes i flere danske oversættelser på Oehlenschlägers tid, ${ }^{\text {II }}$ omskriver og tilpasser han den alligevel, så den stemmer overens med hans egen genfortælling om Regnar Lodbrog. Han rekonstruerer digtet, fremhæver eller tilføjer vemodige passager og lader Regnar udgive sig for at være skjald. Derved kan Regnars dødssang siges at føje en helt ny og intertekstuel kontekst til Oehlenschlägers bog: Den afspejler forfatterens egen rekonstruktion af digtet, idet Regnar genfortolker sin egen fortælling. I samme omgang vælger Regnar at skabe et nyt billede af sig selv som skjald. Dødssangen i Regnar Lodbrok fortæller således mere om Oehlenschlägers fortolkning af sagnhelten end om de kilder, som heltedigtet bygger på.

Oehlenschlägers og Hirsts versioner af "Krákumál" har konsekvenser for vores billede af vikingetiden og vikingen Regnar Lodbrog. Selvom Regnar Lodbrok ikke har haft den store receptionshistorie, var dens forfatter Oehlenschläger og flere andre romantikere med til at sikre, at vikingetiden fik en central plads i danskernes nationale identitet og kollektive erindring. Vikings markerer vikingernes indflydelse i 
populærkulturen, men serien formår også at påvirke forskningsmiljøer (jf. Nationalmuseets udstilling "Mød vikingerne"). Samtidig er den med til at gøre norrøn litteratur og poesi mere tilgængelig for seere over hele verden. Regnar Lodbrogs dødssang bliver i serien udtalt af en moderne, self-made helt i vikingeklæder, hvorimod Oehlenschläger lader en splittet og sympatisk krigerskjald synge sin dødssang og finde fred deri.

\section{Noter}

I “Mød vikingerne” vil i de næste år være en fast del af Nationalmuseets samlede udstilling om den nordiske oldtid. Eksperter har bl.a. beskyldt udstillingen for at være en "politisk-taktisk", "historieløs udklædningsleg” (Seerup 2018; Sindbæk 2018). Udstillingens museumsinspektører har forsvaret sig med påstanden om, at de ønsker at udfordre grænserne for, "hvordan man kan formidle vikingetiden" (Varberg, Pentz og Petersen 2018). Åbningsdebatten kan ses på Nationalmuseets hjemmeside.

2 Jeg henviser her til dokumentarserien "Secrets of the Vikings" på History’s youtube-kanal. På History's hjemmeside kan man ligeledes læse baggrundsartikler om vikingernes historie og traditioner.

3 Regnars replik bygger sandsynligvis på Carolyne Larringtons oversættelse af "Hávamál" fra 1996, som Evans også henviser til i den forbindelse (Evans 2017, 206).

4 Robert Rix har skrevet en grundig artikel om receptionen af "Krákumál" i 1600- og 1700-tallets England. Flere indflydelsesrige antikvarer oversatte og refererede til digtet, herunder Robert Sheringham (i 1670) og Thomas Percy, som i 1763 skrev den første komplette engelske oversættelse baseret på Ole Worms latinske version fra 1636. Som det fremgår hos Rix, blev dødssangen brugt til både at dæmonisere og idyllisere den nordiske dødsforagt, og visse antikvarer henviste til digtet for at fremme nationens germanske rødder (Rix 2009, 56ff). "Krákumál" indgik også i diskussionen omkring James Macphersons Ossian-digte (1760-1765). F.eks. karakteriserede Macphersons ven Hugh Blair Regnars dødssang som et barskt modstykke til Ossians følsomme stil (Blair 1996, 349). Udover Rix har Gauti Kristmannsson diskuteret sammenfaldene mellem receptionen af Ossian og den norrøne litteratur i 1700- og 1800-tallet (Kristmannsson 2013; Rix 2017).

5 Rafn genudgav senere samlingen med titlen Nordiske Fortids Sagaer (1829-1830), hvor han inkluderede flere sagaer.

6 Her kan nævnes Oehlenschlägers Vaulundurs Saga (1805), Hagbarth og Signe (1814) og Stærkodder (1812).

7 Nævneværdige er Hakon Jarl (opført 99 gange frem til 1975), Palnatoke (37 opførelser indtil 1975), og Væringerne i Miklagaard, som blev opført 41 gange mellem 1827-1889 ("Adam Oehlenschläger"). For flere detaljer om Oehlenschlägers tragedier henviser jeg til Frederik Ludvig Liebenbergs Den Oehlenschlägerske Literaturs Historie 1-2 (1868) og Alvhild Dvergsdals Oehlenschlägers tragediekunst (1997). Se også fodnote nummer 9.

8 I sit prisessay fra 1800 lægger Oehlenschläger netop vægt på, at det er op til digteren at tilføje nye elementer og forbedre fortidens norrøne kilder (Oehlenschläger 1980, 17f.). Hans adaptationsmetode er også diskuteret for nylig af Lise Præstgaard Andersen i artiklen "Ewald's and Oehlenschläger's Poetry Inspired by Old Norse Myth” (2018). 
9 Antal opførelser af Oehlenschlägers teaterstykker kan undersøges via hjemmesiden forfatterleksikon.dk og Liebenbergs Bidrag til den Oehlenschlägerske Literaturs Historie 1-2 (se litteraturlisten). Derimod er det samlede oplægs- og salgstal for Oehlenschlägers bøger fortsat uvist. Denne information kunne ellers klargøre, hvor stor en læserskare forfatteren rent faktisk havde, og tallene kunne også indikere, om hans genfortællinger af norrønt stof kan betegnes som et succesrigt formidlingsprojekt.

Io Robert Sheringham var i 1670 den første til at diskutere "Krákumál" ud fra strofe 25 og 29, og de blev sidenhen anvendt af flere engelske antikvarer, der ville beskrive vikingetidens særtræk (Rix 2009, 55).

II Foruden Viborgs og Rafns oversættelser har Oehlenschläger også haft adgang til en dansk version af "Krákumál" via Bertel Christian Sandvigs antologi Danske Sange af det ældste Tidsrum (1779). Hos Sandvig har Regnars dødssang titlen "Biarkemaal, sjunget af Kong Regner Lothbrog" (Sandvig 1779, 37).

\section{Litteratur}

"Adam Oehlenschläger", oversigt på forfatterleksikon.dk, http://danskforfatterleksikon. dk/1850bib/oadamoehlenschlager.htm\#Dramatik (18.12.2018).

www.history.org: "Interview with Michael Hirst (creator of Vikings)" på History's hjemmeside, https://www.history.co.uk/shows/vikings/articles/interview-with-michael-hirst-creator-of-vikings (18.12.2018).

Bjerre, Signe (2016): "Vikingemuseer jubler: Tv-serier om vikinger tiltrækker tusindvis af ekstra besøgende”, DR, udgivet d. 18. maj 2016, https://www.dr.dk/nyheder/kultur/historie/vikingemuseer-jubler-tv-serier-om-vikinger-tiltraekker-tusindvis-af-ekstra (18.12.2018).

Blair, Hugh (1996/1763): "A Critical Dissertation on the Poems of Ossian, the Son of Fingal”, i Howard Gaskill (red): The Poems of Ossian and related works, Edinburgh: Edinburgh University Press, s. 343-408.

Bohsen, Gerda og René Just Poulsen (2016): "VIDEO Serien 'Vikings' får turister til at stå i kø til danske museer", DR, udgivet d. 18. maj 2016, https://www.dr.dk/nyheder/kultur/historie/videoserien-vikings-faar-turister-til-staa-i-koe-til-danske-museer (18.12.2018).

Clunies Ross, Margaret (2001): The Old Norse poetic translations of Thomas Percy, Turnhout: Brepols. Donnely, Ciarán (instruktør, 2016): “All his Angels”, i Vikings.

Driscoll, Matthew (2018): "Introduction: The Transmission and reception of the fornaldarsögur Norðurlanda”, i Matthew Driscoll, Silvia Hufnagel, Philip Lavender og Beeke Stegmann (red.): The Legendary Legacy. Transmission and reception of the Fornaldarsögur Norðurlanda, København: University Press of Southern Denmark, s. 9-17.

Dvergsdal, Alvhild (1997): Oehlenschlägers tragediekunst, København: Museum Tuschulanums Forlag.

Evans, Gareth Lloyd (2017): "Michael Hirst's Vikings and Old Norse Poetry", i Tom Birkett og Kirsty March-Lyons (red.): Translating Early Medieval Poetry. Transformation, Reception, Interpretation, Cambridge: D. S. Brewer, s. 199-212.

Kristmannsson, Gauti (2013): "Ossian in the North", i Translation and Literature 22, s. 361-382.

Hermann, Pernille (2017): “The Vikings! Vikinger i populærkultur og kollektiv erindring”, 16:9, udgivet 24. april, http://www.16-9.dk/2017/04/the-vikings/ (18.12.2018). 
Lassen, Annette (red. og oversætter, 2016): Oldtidssagaerne 1, København: Gyldendal.

Lassen, Annette (2018): "The fornaldarsögur in Danish translation: From Carl Christian Rafn to the present", i Matthew Driscoll, Silvia Hufnagel, Philip Lavender og Beeke Stegmann (red.): The Legendary Legacy. Transmission and reception of the Fornaldarsögur Norðurlanda, København: University Press of Southern Denmark, s. 323-350.

Liebenberg, Frederik Ludvig (1868): Bidrag til den Oehlenschlägerske Literaturs Historie 1-2, København: Schultz.

Oehlenschläger, Adam (1840): Nordiske Oldsagn, bearbeidede til Almeenlæsning, København: Selskabet for Trykkefrihedens rette Brug.

Oehlenschläger, Adam (1849): Regnar Lodbrok: et Heltedigt, København: Høst.

Oehlenschläger, Adam (1851): Erindringer, nr. 4, København: Høst.

Oehlenschläger, Adam (1980/1800): "Forsøg til Besvarelse af det ved Kiøbenhavns Universitet fremsatte Priisspørgsmål”, i F. J. Billeskov Jansen (red.): Estetiske skrifter 1800-1812, Herning: Oehlenschläger Selskabet, s. 5-22.

Oehlenschläger, Adam (1990/1844-1850): Breve til og fra Adam Oehlenschläger III, København: Det danske Sprog- og Litteraturselskab.

Poulsen, Allan Bo og Natacha Tjørnholm (2017): "Vikinger erobrer turister: Museers billetsalg stormer frem”, DR, udgivet d. 27. april 2017, https://www.dr.dk/nyheder/regionale/midtvest/vikingererobrer-turister-museers-billetsalg-stormer-frem (18.12.2018).

Præstgaard Andersen, Lise (1981): “Oehlenschläger, de norrøne kilder og de norrøne kvinder”, i Danske studier 76.4, s. 5-31.

Præstgaard Andersen, Lise (2018): “Ewald's and Oehlenschläger's Poetry Inspired by Old Norse Myth”, i Margaret Clunies Ross (red.): The Pre-Christian Religions of the North: Research and Reception, Volume 1: From the Middle Ages to c. 1830, Turnhout: Brepols, s. 331-350.

Rix, Robert (2009): “The Afterlife of a Death Song: Reception of Ragnar Lodbrog's Poem in Britain Until the End of the Eighteenth Century", i Studia Neophilologica 81.1., s. 53-68.

Rix, Robert (2015): “In darkness they grope’: Ancient Remains and Romanticism in Denmark”, i European Romantic Review 26.4, s. 435-451.

Rix, Robert (2017): “Ossian's Impact on the Discovery of Ancient Scandinavian Literature”, i Dafydd Moore (red.): The International companion to James Macpherson and The poems of Ossian, Glasgow: Scottish Literature International, s. 76-91.

Rowe, Elizabeth Ashman (2009): "Ragnars saga Lodðbrókar, Ragnarssona páttr, and the Political World of Haukr Erlendsson”, i Agneta Ney, Ármann Jakobsson og Annette Lassen (red.): Fornaldarsagaerne. Myter og virkelighed, København: Museum Tusculaniums Forlag, s. 347-360.

Sandvig, Bertel Christian (1779): Danske Sange af det ældste Tidsrum, indeholdende blandt andet nogle Danske og Norske Kongers Bedrifter, København: A. H. Gofiches Efterleverskes Forlag (Kongelige Universitets Bogtrykkerie).

Seerup, Jakob (2018): “Rane Willerslev, Nationalmuseet, Jim Lyngvild og kulturarven”, i POV International, udgivet d. 15. november 2018, https://pov.international/rane-willerslev-nationalmuseetjim-lyngvild-og-kulturarven/ (18.12.2018).

Sindbæk, Søren (2018): “Tro det ... eller lad være: Nationalmuseets udstilling på vildspor”, POV International, udgivet 28. november 2018, https://pov.international/tro-det-eller-lad-vaere-nationalmuseets-vikingeudstilling-pa-vildspor/?fbclid=IwAR2Plezo1qW0cZjTHSnkkvkdvoMSk4Z61zXHs VV62G6XdvggGFhAXFhjrTk (18.12.2018).

Svane, Marie-Louise (2008): “Romantikkens gennembrud - Adam Oehlenschläger”, i Klaus P. Mor- 
tensen og May Shack (red.): Dansk litteraturs historie bd. 2: 1800-1870, København: Gyldendal, s. 100-141.

Swinson, Brock (2016): “I could hear their voices.' Michael Hirst on Vikings", i Creative Screenwriting, udgivet 30. november 2016, https://creativescreenwriting.com/vikings/ (18.12.2018)

Varberg, Jeanette, Peter Pentz og Peter Vang Petersen (2018): "God videnskab udfordrer vores viden”, i POV International, udgivet d. 29. november 2018, https://pov.international/god-videnskab-udfordrer-vores-viden/ (18.12.2018). 